\author{
B. Abdrasilov ${ }^{1}$, Zh. Kudaibergenov ${ }^{2, *}$, D. Kelesbayev ${ }^{3}$, S. Baimaganbetov ${ }^{4}$ \\ ${ }^{1,2,3,4}$ Khoja Akhmet Yassawi International Kazakh-Turkish University, Turkestan, Kazakhstan \\ 'b.abdrasilov@ayu.edu.kz, ${ }^{2} j a n d o s . k u d a i @ a y u . e d u . k z$, \\ 3dinmukhamed.kelesbayev@ayu.edu.kz, ${ }^{4}$ sabit.baymaganbetov@ayu.edu.kz \\ ${ }^{1}$ http://orcid.org/0000-0002-9716-5260, ${ }^{2}$ http://orcid.org/0000-0002-7927-8747, \\ ${ }^{3}$ http://orcid.org/0000-0002-4193-8121, ${ }^{4}$ https://orcid.org/0000-0003-2099-5562 \\ ${ }^{I}$ Scopus Author ID: 6603298330, ${ }^{3}$ Scopus Author ID: 56623085400, ${ }^{4}$ Scopus Author ID: 56907030500 \\ ${ }^{1}$ ResearcherID: AAS-7016-2020, ${ }^{2}$ ResearcherID: AAE-2355-2021, ${ }^{3}$ ResearcherID: P-2783-2017
}

\title{
Analysis of human resources management practices: the impact of training on performance efficiency of employees of Akhmet Yassawi University
}

\begin{abstract}
Object: Human resources management (HRM) provides the necessary guidance in order to reach the most efficient result through the most effective way. This paper aims to determine the relation between the descriptive characteristics and HRM practices, and the impact of training practices on the performance of employees.

Methods: The authors used the questionnaire method in collecting data and the 5-point Likert system to assess them. Then, the obtained data were analyzed by using SPSS Statistics program. The authors applied the factor analysis, T-test, ANOVA test, regression analysis methods.

Findings: This paper determines the impact of training practices, namely, the satisfaction factor and motivation factor, to the performance efficiency of the employees. When the satisfaction factor increases by one unit, the performance level will decrease by 0.145 units. There is a positive correlation between the performance and the motivation factor. If the motivation factor increases by one unit, performance level will also increase by 0.413 units.

Conclusion: Training activities increase the professional and technical knowledge of the employees as well as improve their abilities and corporate culture. Thus, it is necessary to provide a working environment where employees can continuously learn and develop themselves through training.
\end{abstract}

Keywords: human resources management, HRM practices, training, performance efficiency, university, satisfaction factor, motivation factor, employee, lecturer.

\section{Introduction}

Organizations, which effectively manage and use human resources, are more successful than organizations that do not use human resources effectively. Effective use of human resources is realized by a strong HRM policy, high motivation and effective performance management (Leroy et al., 2018). The wellstructured performance management application also enables HRM to fulfill its functions in the organization. Training influences employee performance by gaining special skills in order to create a product from their work (S. Sharma \& Taneja, 2018). Although employees have the skills and knowledge to do their current jobs, they also need to be prepared for future jobs. For this reason, having the knowledge and skills to carry out the works in the next period is achieved through the implementation of development programs (Ibrahim et al., 2017). The newly recruited employee should be continuously trained in order to keep up with the changes and developments, which required by their jobs from the time they start working until they quit (McCrie, 2007).

Qualitative or quantitative analysis of all the efforts, which put forward in order to achieve the organization's goals, reveal the performance. Employees are required to be aware of the expectations and performance standards of the management. Objectively evaluating employee performance is possible through a comparative analysis of the organization's standards or forms in certain periods (Khan et al., 2011).

While constantly changing environmental conditions, new competition conditions and market structures are a necessity for organizations to survive through adaptation, organizations can demonstrate their existence in this way. Some of the goals of the universities are to ensure the satisfaction of individuals in the higher education sectors, to ensure work commitment, to provide faster, flexible and quality service (Shibayama, 2019). In the developing digital world with more automation and technological developments, the need for manpower is increasing, and new horizons can be opened in this sector.

\footnotetext{
${ }^{*}$ Corresponding author.

E-mail address: jandos.kudai@ayu.edu.kz
} 
This paper aims to determine the relation between the descriptive characteristics and HRM practices, and the impact of training on the performance of employees. HRM provides the necessary guidance in order to reach the most efficient result through the most effective way. It includes all employees of the organization from the lowest unskilled worker to the top management. The organizations are unlikely to be successful if they don't have an effective HRM policy, even sufficient of the financial resources does not help.

The importance of this research is to reveal the impact of training on performance. The organizations have to keep qualified personnel at the highest level of satisfaction. The organizations, whose work environments are not structured satisfactorily and pleasantly, will meet the difficulties in retain qualified personnel (Afshari et al., 2010). It is very difficult for newly employed personnel, who are getting oriented to the workplace and working conditions. In order to reduce such problems encountered in the recruitment process and to make positive changes in the performance of the employees, organizations have to give importance to training programs. Training improves the performance of personnel by gaining special skills. In other words, training is considered as an investment in human resources. The main purpose of the training is to reduce the current low performance and increase the productivity rate (Barba Aragón et al., 2014). Rapidly changing environmental conditions, new competitive conditions and market structures are a requirement for companies to survive through adaptation. So, only organizations, which maintain their existence as an open system, can maintain their continuity (Mpofu \& Hlatywayo, 2015). Ensuring satisfaction in the higher education sector, creating loyalty to work and providing better quality are the main goals of universities.

The significance of this research is to examine the training activities in Akhmet Yassawi University. This paper determines the opinions and expectations of the respondents, the problems, deficiencies and mistakes related to the training activities, and the recommendations for solving of these problems. In this respect, the results of this study provide an opportunity to create a different vision and idea in developing HRM practices in universities. The increase of employees' (lecturers and staff) performance helps to obtain good results in quality. This situation is an important phenomenon for lecturers and university management.

Training is important and directly affects the efficiency of the organizations. Hence, we have tried to prove the following hypotheses:

H1: The gender of the employees impacts on training and performance factors.

H2: The marital status of the employees impacts on training and performance factors.

H3: Academic rank impacts on training and performance factors.

H4: Work experience in Akhmet Yassawi University impacts on training and performance factors.

H5: Training factors impact on performance of the employees.

\section{Literature Review}

Education consists of a process to gain knowledge and experience. According to Chahar et al. (2019) training is to ensure that employees improve their current knowledge, skills, experience and competence. The need for training varies significantly according to the profession and field of activity. In practice, a lot of large organizations establish the training departments within their organization or employ external coaches for training. Training has great importance in contributing to the achievement of organizations' goals. This activity needs time and a certain expense. Adapting to changing environmental conditions is very important for an organization, and this is possible only through training. Vinesh (2014) stated that, firstly, it should be determined the necessity of training activities, and then these needs should be planned and put into practice.

Organizations can only survive if they achieve their existential purpose. The employee, as an important element, should be carefully examined. In order to ensure the efficiency and effectiveness of the organization, the qualifications of the employees must be appropriate and compatible with the organization. Training seems to be one of the most effective elements of achieving this (Galvão et al., 2020). Training should be at the top of the issues of importance for the organization in the changing competitive environment.

According to Singh (2018) it is possible to define performance appraisal as a systematic evaluation tool that enables employees to realize their potential, sets goals for organizations, teams and employees to achieve more effective results, and consists of evaluation, feedback and rewarding stages. Performance appraisal has significant contributions to employees to achieve their goals, to identify what is expected of them, to identify training needs, and to establish quality communication with their managers. From the point of view of Sharma et al. (2020) the manager should provide constructive and unbiased feedback to his employees, be more effective in guidance, plan their professional development rationally, and ensure the integration of the organization's goals with the goals of the employee. Performance appraisal system consists of studies 
that include the detection and correction of deviations, the evaluation results of the performance and the ways of its improvement (Daoanis, 2012). In order to increase the effectiveness of this system, it should be supported by training programs and other communication tools. Thanks to this system, it is aimed to identify the goals and to monitor and evaluate the employee development needs. Gruman \& Saks (2011) stated that if the system is applied fairly and under correct conditions, it may be possible to use the results, which are obtained as inputs to other human resources management practices.

\section{Methods}

We used the questionnaire method in collecting data. There were questions to determine the descriptive characteristics of the respondents in the first part of the questionnaire form. In the second part of the questionnaire, two different variables were used to measure perceptions of training practices. These variables consist of satisfaction and motivation for training activities. The third part includes questions about the assessment of the performance of the employees. The questionnaire consists of 19 questions in total. We used the 5-point Likert system in the questionnaire with the five levels of answers: 1-strongly disagree, 2-disagree, 3-indecisive, 4-agree, 5-strongly agree. Then, the obtained data from the applied questionnaire were coded and analyzed by SPSS 20.0 Statistics program. With the help of this program, we applied the factor analysis, T-test, ANOVA test, regression analysis.

The research is limited to Akhmet Yassawi University lecturers and staff only. Therefore, the study findings are limited to the sample and the questionnaire answers. The sample was applied to all employees of Akhmet Yassawi University, but only 205 questionnaires were answered and accepted as valid.

\section{Results and Discussion}

In order to understand the general situation, we decided to make following frequency statistics analysis. Table 1 concerning the gender distribution shows that $107(52.2 \%)$ respondents were male, 98 (47.8\%) were female out of a total of 205 respondents. It means that male is little more than female.

Table 1. Frequency statistics of gender

\begin{tabular}{|l|l|c|c|c|c|}
\hline \multicolumn{2}{|c|}{} & Frequency & Percent & Valid Percent & Cumulative Percent \\
\hline \multirow{3}{*}{ Valid } & Male & 107 & 52,2 & 52,2 & 52,2 \\
\cline { 2 - 6 } & Female & 98 & 47,8 & 47,8 & 100,0 \\
\cline { 2 - 5 } & Total & 205 & 100,0 & 100,0 & \\
\hline \multicolumn{2}{|l}{ Note - Compiled by the author on the basis of questionnaire } \\
\hline
\end{tabular}

The marital status distribution stated that 145 (70.7\%) respondents were married, $56(27.3 \%)$ were single, and $4(2 \%)$ were divorced. Table 2 shows that the number of married employees is higher.

Table 2. Frequency statistics of marital status

\begin{tabular}{|l|l|c|c|c|c|}
\hline \multicolumn{2}{|c|}{} & Frequency & Percent & Valid Percent & Cumulative Percent \\
\hline \multirow{5}{*}{ Valid } & Married & 145 & 70,7 & 70,7 & 70,7 \\
\cline { 2 - 5 } & Single & 56 & 27,3 & 27,3 & 98,0 \\
\cline { 2 - 5 } & Divorced & 4 & 2,0 & 2,0 & 100,0 \\
\cline { 2 - 5 } & Total & 205 & 100,0 & 100,0 & \\
\hline \multicolumn{2}{|l|}{ Note - Compiled by the author on the basis of questionnaire } \\
\hline
\end{tabular}

As it is seen in the Table 3, $25(12.2 \%)$ respondents were professors, $52(25.4 \%)$ were associate professors, $46(22.4 \%)$ were senior lecturers, 47 (22.9\%) were assistant professors, and 35 people (17.1\%) had no ranks. It proves that most of the employees in this sector are associate professors.

Table 3. Frequency statistics of academic rank

\begin{tabular}{|c|c|c|c|c|c|}
\hline & & Frequency & Percent & Valid Percent & Cumulative Percent \\
\hline \multirow{6}{*}{ Valid } & Professor & 25 & 12,2 & 12,2 & 12,2 \\
\hline & Associate Professor & 52 & 25,4 & 25,4 & 37,6 \\
\hline & Senior Lecturer & 46 & 22,4 & 22,4 & 60,0 \\
\hline & Assistant Professor & 47 & 22,9 & 22,9 & 82,9 \\
\hline & No rank & 35 & 17,1 & 17,1 & 100,0 \\
\hline & Total & 205 & 100,0 & 100,0 & \\
\hline
\end{tabular}


The distribution of the work experience in this university shows that $35(17.1 \%)$ respondents have been working for less than 1 year, $65(31.7 \%)$ for $1-5$ years, $47(22.9 \%)$ for $6-10$ years, and $58(28.3 \%)$ for above 11 years. It means that most of the employees in this sector have been working in this university for $1-5$ years.

Table 4. Frequency statistics of work experience in Akhmet Yassawi University

\begin{tabular}{|l|l|l|l|l|l|}
\hline \multicolumn{1}{|c|}{} & Frequency & Percent & Valid Percent & Cumulative Percent \\
\hline \multirow{5}{*}{ Valid } & Less than 1 year & 35 & 17,1 & 17,1 & 17,1 \\
\cline { 2 - 6 } & $1-5$ years & 65 & 31,7 & 31,7 & 48,8 \\
\cline { 2 - 6 } & $6-10$ years & 47 & 22,9 & 22,9 & 71,7 \\
\cline { 2 - 6 } & 11 and above & 58 & 28,3 & 28,3 & 100,0 \\
\cline { 2 - 6 } & Total & 205 & 100,0 & 100,0 & \\
\hline \multicolumn{4}{|l}{ Note- Compiled by the author on the basis of questionnaire } \\
\hline
\end{tabular}

Reliability Analysis

Reliability analysis is used to measure the level of trust in the survey research questions. Determining the reliability level is made by looking at the reliability coefficient. The reliability coefficient takes values between 0 and 1 (Table 5)

Table 5. Reliability coefficient

\begin{tabular}{|c|c|}
\hline Cronbach Alpha Value & Reliability status \\
\hline $0.00<$ Cronbach Alpha coefficient $<0.40$ & Not Reliable \\
\hline $0.40<$ Cronbach Alpha coefficient $<0.60$ & Low Reliability \\
\hline $0.60<$ Cronbach Alpha coefficient $<0.80$ & Reliable \\
\hline $0.80<$ Cronbach Alpha coefficient $<1.00$ & High Reliability \\
\hline Note - Compiled by the author & \\
\hline
\end{tabular}

The reliability analysis shows the Cronbach's Alpha coefficient for the whole study as 0.820 . It means that the reliability of the research is high. Besides the Cronbach's Alpha coefficient for the whole study, it is calculated the Cronbach's Alpha coefficients for each level individually. Cronbach's Alpha coefficient took its lowest value (0.691) at the Performance level.

Factor Analysis

Factor analysis aims to reduce the number of analyzes to be made in order to reach a simpler result that is easier to understand and analyzes to be made by collecting questions with similar purposes under a single heading. However, factor analysis cannot be applied to every data set. The KMO value of the analyzing data sets should be high, and the Bartlett test statistic result should be significant, that is, it must be less than alpha (0.05). KMO value is a coefficient value indicating the size of the relationship between variables. KMO value takes a value between 0 and 1 . While the relationship between variables increases, the KMO value approaches 1, when it decreases, it approaches 0 (Harrington, 2009).

This paper suggests the factor analysis, which was applied for HRM practices such as personnel training and performance. This study's p-value was calculated as 0.000 by the result of Bartlett test statistics. While the $p$-value is smaller than the alpha value, the test statistic was significant $(\mathrm{p}=0.00<\mathrm{Alpha}=0.05)$. In other words, it has been determined that it is appropriate to apply factor analysis on training and performance practices.

As a result of the factor analysis on the training and the performance factors, it was determined that each variable had one component matrix. The reliability coefficient, the mean and standard deviation values of the variables were also calculated (Table 6).

Table 6. Factor analysis for personnel training and performance practices

\begin{tabular}{|c|c|c|c|c|c|c|c|}
\hline \multirow{2}{*}{ № } & \multirow{2}{*}{ HRM practices } & \multirow{2}{*}{ Factor } & \multicolumn{4}{|c|}{ Bartlett Test statistic Sig. $=\mathbf{0 , 0 0 0}$} & \multirow{2}{*}{$\begin{array}{c}\text { Component } \\
\text { matrix }\end{array}$} \\
\hline & & & Questions & Mean & Std. Deviation & Alpha & \\
\hline 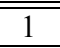 & 2 & 3 & 4 & 5 & 6 & 7 & 8 \\
\hline \multirow{3}{*}{1} & \multirow{3}{*}{ Training } & \multirow{3}{*}{$\begin{array}{l}\text { Satisfaction } \\
\text { factor }\end{array}$} & Q5 & 4,04 &, 845 & \multirow{3}{*}{,789 } & ,741 \\
\hline & & & Q6 & 3,89 & 1,160 & & ,802 \\
\hline & & & Q7 & 4,11 & 1,077 & & ,824 \\
\hline
\end{tabular}




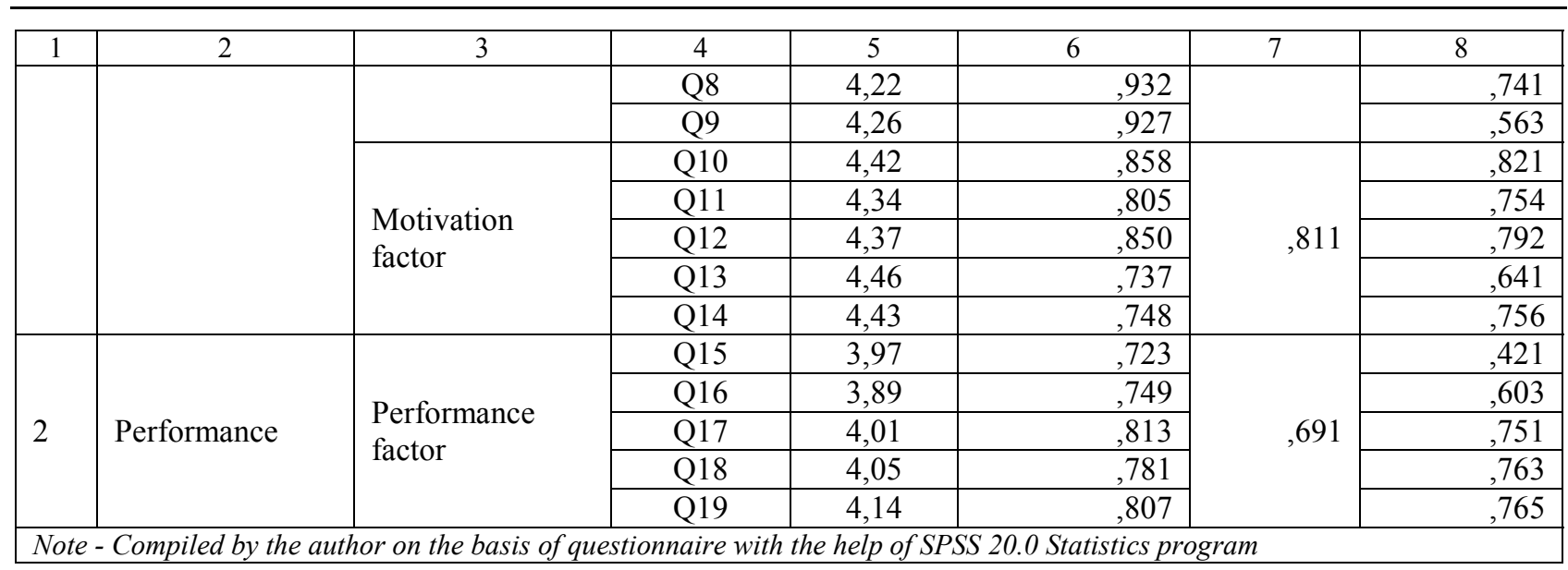

According to Table 7, the reliability coefficient of the performance factor is the smallest coefficient, that is, 0.691. This means that the study is reliable even at the smallest value, which belongs to the performance factor.

Table 7. Factor analysis' results by factors

\begin{tabular}{|c|c|c|c|c|c|c|c|}
\hline \multirow[b]{2}{*}{ № } & \multirow[b]{2}{*}{ HRM practices } & \multirow[b]{2}{*}{ Factor } & \multirow{2}{*}{$\begin{array}{l}\text { Range of } \\
\text { questions }\end{array}$} & \multirow{2}{*}{$\begin{array}{l}\text { Number of } \\
\text { questions }\end{array}$} & \multicolumn{3}{|c|}{ Cronbach's Alpha } \\
\hline & & & & & by factors & $\begin{array}{l}\text { by HRM } \\
\text { practices }\end{array}$ & $\begin{array}{l}\text { whole } \\
\text { study }\end{array}$ \\
\hline \multirow{2}{*}{1} & \multirow{2}{*}{ Training } & $\begin{array}{l}\text { Satisfaction } \\
\text { factor }\end{array}$ & Q5-Q9 & 5 & ,789 & \multirow{2}{*}{,839 } & \multirow{3}{*}{820} \\
\hline & & $\begin{array}{l}\text { Motivation } \\
\text { factor }\end{array}$ & Q10-Q14 & 5 &, 811 & & \\
\hline 2 & Performance & $\begin{array}{l}\text { Performance } \\
\text { factor }\end{array}$ & Q15-Q19 & 5 & ,691 & ,691 & \\
\hline
\end{tabular}

\section{T-test and ANOVA test analysis}

ANOVA test is the analysis, which examines the relationship between study subjects and categorical variables. If the categorical variable has two sub-categories (gender: male, female), the relationship between the categorical variable and the study subject is tested with the T-test. If the categorical variable has more than two sub-categories, the relationship between the study subject and the categorical variable is examined with the one-way ANOVA test (Holcomb et al., 2018). While T-test uses t value for detecting differences, one-way ANOVA test uses F value. However, in package programs such as SPSS, the p-value is calculated for both the t-test and the one-way ANOVA test to make it easy to detect the differences. If the p-value is smaller than the value alpha (0.05), the difference between the relevant variables is found as significant.

Table 8 shows the relationship between gender and HRM practices.

Table 8. T-test for gender and HRM practices

\begin{tabular}{|c|c|c|c|c|c|c|c|c|}
\hline № & HRM practices & Factor & Gender & $\mathbf{N}$ & Mean & $\begin{array}{c}\text { Std. } \\
\text { Deviation }\end{array}$ & $\mathbf{t}$ & Sig. \\
\hline \multirow{4}{*}{1} & \multirow{4}{*}{ Training } & \multirow{2}{*}{$\begin{array}{l}\text { Satisfaction } \\
\text { factor }\end{array}$} & Male & 107 & 4,1869 &, 61875 & \multirow{2}{*}{1,714} & \multirow{2}{*}{,088 } \\
\hline & & & Female & 98 & 4,0122 & ,83274 & & \\
\hline & & \multirow{2}{*}{$\begin{array}{l}\text { Motivation } \\
\text { factor }\end{array}$} & Male & 107 & 4,4187 & ,41348 & \multirow{2}{*}{,365 } & \multirow{2}{*}{, 715} \\
\hline & & & Female & 98 & 4,3878 &, 76242 & & \\
\hline \multirow{2}{*}{2} & \multirow{2}{*}{ Performance } & \multirow{2}{*}{$\begin{array}{l}\text { Performance } \\
\text { factor }\end{array}$} & Male & 107 & 4,0393 & , 43214 & \multirow{2}{*}{,766 } & \multirow{2}{*}{,445 } \\
\hline & & & Female & 98 & 3,9837 & ,60012 & & \\
\hline
\end{tabular}

H1: The gender of the employees impacts on training and performance factors. 
It was used T-test to examine the differences according to the gender variable. The p-values of training and performance factors are higher than 0.05 . Hence, the H1 hypothesis is not proved. In other words, training and performance factors do not depend on gender.

The rapidly changing needs affect the expectations of family members and cause role changes within the family. Increasing and changing needs enable women to enter working life rapidly and to increase their number. Although men have taken a much more active role in social life, women have started to take place in different responsibilities and duties in time. Men and women have common values in society and social life. However, they undertake different roles as a requirement of the gender roles defined for them in cultural terms. While women take part in working life as free individuals, they also try to behave in accordance with gender roles in society. Therefore, according to the results of this study, there is not much responsibility given to male employees in terms of their satisfaction with their training level and social life in comparison with women, although they focus better on training activities.

Providing the training opportunities for male and female employees at the university, having goals of these employees, being supported by their colleagues and managers to achieve these goals affect their performance levels. The high quality of work affects productivity positively in terms of the performance and commitment of the employees to the university. The decrease in the work quality negatively affects the performance and can lead to the turnover of employees. This study determined that the performance has no significance according to gender $(0.05<0.445)$.

Table 9 shows the relationship between marital status and HRM practices.

Table 9. ANOVA test analysis of marital status and HRM practices

\begin{tabular}{|c|c|c|c|c|c|c|c|c|}
\hline № & HRM practices & Factor & $\begin{array}{l}\text { Marital } \\
\text { status }\end{array}$ & $\mathbf{N}$ & Mean & $\begin{array}{c}\text { Std. } \\
\text { Deviation }\end{array}$ & $\mathbf{F}$ & Sig. \\
\hline \multirow{6}{*}{1} & \multirow{6}{*}{ Training } & \multirow{3}{*}{$\begin{array}{l}\text { Satisfaction } \\
\text { factor }\end{array}$} & Married & 145 & 4,1407 &, 68764 & \multirow{3}{*}{1,927} & \multirow{3}{*}{, 148 } \\
\hline & & & Single & 56 & 4,0536 &, 78670 & & \\
\hline & & & Divorced & 4 & 3,4500 & 1,32035 & & \\
\hline & & \multirow{3}{*}{$\begin{array}{l}\text { Motivation } \\
\text { factor }\end{array}$} & Married & 145 & 4,3710 & ,64420 & \multirow{3}{*}{,771 } & \multirow{3}{*}{,464 } \\
\hline & & & Single & 56 & 4,4893 & ,42455 & & \\
\hline & & & Divorced & 4 & 4,4000 & 1,20000 & & \\
\hline \multirow{3}{*}{2} & \multirow{3}{*}{ Performance } & \multirow{3}{*}{$\begin{array}{l}\text { Performance } \\
\text { factor }\end{array}$} & Married & 145 & 3,9600 & 55907 & \multirow{3}{*}{3,682} & \multirow{3}{*}{,027 } \\
\hline & & & Single & 56 & 4,1143 & 35339 & & \\
\hline & & & Divorced & 4 & 4,5000 & 60000 & & \\
\hline
\end{tabular}

H2: The marital status of the employees impacts on training and performance factors.

When analyzing the affect of marital status on the training, it appears the need for an employee profile that emphasizes on analysis of the work and development, on increasing the importance of quality, as well as on the development of relations between management and employees. In this case, training activities have great importance. Training increases the employee's self-confidence, job satisfaction and performance, and enables him to realize himself. Married employees believe that improving their education positively affects their work and family life, but single employees' expects that trainings help them to make a career. This study results show no significance according to marital status $(0.05<0.148$ and 0.464$)$. Therefore, the $\mathrm{H} 2$ hypothesis is not accepted for training, but it is accepted for performance, because the $p$-value of the performance $(p=0.027)$ factor is less than 0.05 . In analyzing the effect of marital status on the performance of university employees, results shows that university with qualified employees can achieve success. As well as recruiting qualified employees at the university, it is important that they meet their expectations in order to retain these employees in the university. With the effect of the high responsibilities brought by marriage, the commitment of the married people to the job is higher than the singles. These employees can show higher performance in order not to lose their jobs.

Table 10 shows the relationship between academic rank and HRM practices. 
Table 10. ANOVA test analysis of academic rank and HRM practices

\begin{tabular}{|c|c|c|c|c|c|c|c|c|}
\hline № & HRM practices & Factor & Academic rank & $\mathbf{N}$ & Mean & $\begin{array}{c}\text { Std. } \\
\text { Deviation }\end{array}$ & $\mathbf{F}$ & Sig. \\
\hline \multirow{10}{*}{1} & \multirow{10}{*}{ Training } & \multirow{5}{*}{$\begin{array}{l}\text { Satisfaction } \\
\text { factor }\end{array}$} & Professor & 25 & 4,3440 & ,32924 & \multirow{5}{*}{6,160} & \multirow{5}{*}{,000 } \\
\hline & & & $\begin{array}{l}\text { Associate } \\
\text { Professor }\end{array}$ & 52 & 4,2615 & ,53216 & & \\
\hline & & & Senior Lecturer & 46 & 3,8435 & ,96047 & & \\
\hline & & & $\begin{array}{l}\text { Assistant } \\
\text { Professor } \\
\end{array}$ & 47 & 4,3106 & ,46026 & & \\
\hline & & & No rank & 35 & 3,7600 & ,92520 & & \\
\hline & & \multirow{5}{*}{$\begin{array}{l}\text { Motivation } \\
\text { factor }\end{array}$} & Professor & 25 & 4,5840 &, 42786 & \multirow{5}{*}{3,324} & \multirow{5}{*}{,012 } \\
\hline & & & $\begin{array}{l}\text { Associate } \\
\text { Professor }\end{array}$ & 52 & 4,4538 & ,46038 & & \\
\hline & & & Senior Lecturer & 46 & 4,3739 & ,64029 & & \\
\hline & & & $\begin{array}{l}\text { Assistant } \\
\text { Professor }\end{array}$ & 47 & 4,5064 & ,35103 & & \\
\hline & & & No rank & 35 & 4,1029 & ,94852 & & \\
\hline \multirow{5}{*}{2} & \multirow{5}{*}{ Performance } & \multirow{5}{*}{$\begin{array}{l}\text { Performance } \\
\text { factor }\end{array}$} & Professor & 25 & 3,9760 & ,52383 & \multirow{5}{*}{1,613} & \multirow{5}{*}{, 173} \\
\hline & & & $\begin{array}{l}\text { Associate } \\
\text { Professor }\end{array}$ & 52 & 3,9038 & ,47772 & & \\
\hline & & & Senior Lecturer & 46 & 4,0652 & ,45812 & & \\
\hline & & & $\begin{array}{l}\text { Assistant } \\
\text { Professor } \\
\end{array}$ & 47 & 4,1447 &, 45051 & & \\
\hline & & & No rank & 35 & 3,9543 & ,68956 & & \\
\hline
\end{tabular}

H3: Academic rank impacts on training and performance factors.

Table 10 shows that the p-values of training factors are less than 0.05 . Thus, the H3 hypothesis is accepted for training, but not for performance factors, because its p-value is higher than 0.05 .

Table 11. ANOVA test analysis of work experience in Akhmet Yassawi University and HRM practices

\begin{tabular}{|c|c|c|c|c|c|c|c|c|}
\hline № & HRM practices & Factor & $\begin{array}{c}\text { Work experience } \\
\text { in University }\end{array}$ & $\mathbf{N}$ & Mean & $\begin{array}{c}\text { Std. } \\
\text { Deviation }\end{array}$ & $\mathbf{F}$ & Sig. \\
\hline \multirow{8}{*}{1} & \multirow{8}{*}{ Training } & \multirow{4}{*}{$\begin{array}{l}\text { Satisfaction } \\
\text { factor }\end{array}$} & Less than 1 year & 35 & 4,1143 & ,69331 & \multirow{4}{*}{3,053} & \multirow{4}{*}{,030 } \\
\hline & & & $1-5$ years & 65 & 4,0892 & ,74165 & & \\
\hline & & & 6-10 years & 47 & 3,8723 & 83866 & & \\
\hline & & & 11 and above & 58 & 4,3000 & 60321 & & \\
\hline & & \multirow{4}{*}{$\begin{array}{l}\text { Motivation } \\
\text { factor }\end{array}$} & Less than 1 year & 35 & 4,2914 &, 52991 & \multirow{4}{*}{1,964} & \multirow{4}{*}{,121 } \\
\hline & & & $1-5$ years & 65 & 4,5138 & ,39995 & & \\
\hline & & & $6-10$ years & 47 & 4,2766 & 87034 & & \\
\hline & & & 11 and above & 58 & 4,4517 &, 55890 & & \\
\hline \multirow{4}{*}{2} & \multirow{4}{*}{ Performance } & \multirow{4}{*}{$\begin{array}{l}\text { Performance } \\
\text { factor }\end{array}$} & Less than 1 year & 35 & 4,0171 & ,39815 & \multirow{4}{*}{1,657} & \multirow{4}{*}{, 177 } \\
\hline & & & $1-5$ years & 65 & 4,0862 & ,37411 & & \\
\hline & & & 6-10 years & 47 & 3,8723 &, 70702 & & \\
\hline & & & 11 and above & 58 & 4,0414 & 53345 & & \\
\hline
\end{tabular}

H4: Work experience in Akhmet Yassawi University impacts on training and performance factors.

The extension of the employee's work experience in Akhmet Yassawi University, increases the investment of that employee in the university. This means that the employee gets more experience regarding the work he has done during the work period in the university. This affects to the individual gains of employee and positive contributions to the efficiency of the institution. The correct determination of the needs analysis for training activities changes the employee's perspective on training. When analyzing the training factors, it was found that employees with 11 years of work experience or more were higher in training activities than others. The study analysis shows that the satisfaction factor has a significance according to work experience in university $(0.03<0.05)$, but the motivation factor did not have significance 
$(0.05<0.121)$. Therefore, the H4 hypothesis is accepted for training, but not for performance factors, because its p-value is higher than 0.05. Although employees' time can be bought for wages, it is not always possible to buy their loyalty and enthusiasm for the job. These can be achieved by the approach methods towards employees. In addition to the economic expectations of the employees, their expectations and attitudes towards the job affect their performance.

\section{Regression Analysis}

Regression analysis examines the existence of linear relationships between a dependent variable and one or more independent variables, their size and direction. In the regression analysis, beta coefficients are calculated for variables that are found to have a significant relationship between variables (King et al., 2017). Mathematical equations are established with the calculated coefficients. Equation established in terms of regression. It can be expressed as:

$$
Y=\beta 0+\beta i X i+\varepsilon i
$$

Here, $X$-independent variable of $i$;

$Y$ - dependent variable;

$\beta i$-coefficient of the independent variable of $i$;

$\varepsilon i$ - error terms of the dependent variable

$\beta 0$ - constant coefficient value

Table 12. The relationship between performance and training factors

\begin{tabular}{|c|c|c|c|c|c|c|}
\hline \multicolumn{7}{|c|}{ Coefficients $^{\mathrm{a}}$} \\
\hline & \multirow{2}{*}{ Model } & \multicolumn{2}{|c|}{ Unstandardized Coefficients } & \multirow{2}{*}{$\begin{array}{c}\text { Standardized Coefficients } \\
\text { Beta }\end{array}$} & \multirow{2}{*}{$\mathbf{t}$} & \multirow{2}{*}{ Sig. } \\
\hline & & B & Std. Error & & & \\
\hline \multirow{3}{*}{1} & (Constant) & 2,683 &, 255 & & 10,515 & ,000 \\
\hline & Satisfaction Factor &,- 119 &, 052 &,- 168 & $-2,312$ &, 022 \\
\hline & Motivation Factor &, 413 & 062 & ,481 & 6,619 &, 000 \\
\hline
\end{tabular}

a. Dependent Variable: Performance

Regression analysis shows that the calculated p-value is 0,000 and explanation percentage (R2) of the model is 0,182 (Table 13).

Table 13. Model Summary of Regression Analysis

\begin{tabular}{|c|c|c|c|c|c|c|c|c|c|}
\hline \multirow[b]{2}{*}{ Model } & \multirow[b]{2}{*}{$\mathbf{R}$} & \multirow[b]{2}{*}{ R Square } & \multirow{2}{*}{$\begin{array}{l}\text { Adjusted R } \\
\text { Square }\end{array}$} & \multirow{2}{*}{$\begin{array}{l}\text { Std. Error of } \\
\text { the Estimate }\end{array}$} & \multicolumn{5}{|c|}{ Change Statistics } \\
\hline & & & & & R Square Change & F Change & df1 & df2 & $\begin{array}{c}\text { Sig. F } \\
\text { Change }\end{array}$ \\
\hline 1 &, $426^{\mathrm{a}}$ & , 182 & , 174 & ,47155 & , 182 & 22,422 & 2 & 202 &, 000 \\
\hline
\end{tabular}

a. Predictors: (Constant), Motivation Factor, Satisfaction Factor

H5: Training factors impact on the performance of the employees.

As a result of the regression analysis between performance and training factors, performance and constant coefficient $(p=0.000)$, satisfaction factor $(p=0.022)$ and motivation factor $(p=0.000)$ were found to be correlated $(\mathrm{p}<0.05)$. The regression equation is as follows:

The number of factors, which was significant according to regression analysis, is two, so $i$ is equal to 2 $(\mathrm{i}=2)$. Hence, the formula of the equation must be as:

$$
Y=\beta 0+\beta 1 X 1+\beta 2 X 2
$$
lows:

If the symbol equivalents and values in Table 9 are replaced in the equation, we get the equation as fol-

$$
\text { Performance }=2.683-0.119 \text { Satisfaction factor }+0.413 \text { Motivation factor }
$$

As a result of the regression equation, we see a negative relationship of $11.9 \%$ between the performance and the satisfaction factor. When the satisfaction factor increases by one unit, the performance level will decrease by 0.145 units. There is a positive correlation of $41.3 \%$ between the performance and the motivation 
factor. When the motivation factor increases by one unit, the performance level will also increase by 0.413 units.

When the examining the relationship between the performance level of the employees and the satisfaction factor and motivation factor, training and development practices are one of the important issues in terms of efficiency. The general purpose of education systems is to equip individuals with comprehensive knowledge and skills. The aim of formal education systems is to provide individuals with basic knowledge and skills to improve their attitudes and behaviors. Specific issues related to working life are not within the scope of formal training. Thousands of young people graduate from formal education universities that cover different education fields every year and start their work life. However, most of these employees are not prepare for the real work. Thus, their performance decreases and they need training to eliminate the deficiencies in their jobs. One of the goals of managers is to prepare learning environments to increase the performance of employees and to help them gain the habit of lifelong learning.

\section{Conclusion and Recommendations}

This study aimed to determine the affect of the training factors on the performance efficiency factors. With the help of applied questionnaire, we aimed to determine the training programs and which factors affect employees' performance. According to the results we have stated that university generally aims to develop their employees and provide job satisfaction, to increase their productivity, and prevent their alienation from work through orientation trainings. Thus, as a result of the performance evaluation, it was concluded that the employees' job satisfaction and their commitment to the university increased, and they easily adapted to developing technology. The importance of developing training activities is emphasized in order to ensure the continuity of organizations and to adapt to changing environmental conditions. It means that success can be achieved by determining these activities by the needs and organizing them continuously.

This paper determines the effect of training practices, namely, the satisfaction factor and motivation factor, to the performance level of the employees. It has been explained the possibility of increasing the performance of university employees through training and development activities. Academic and professional staff should be trained in order to eliminate the identified training gap and to increase efficiency. It is important to provide the necessary trainings to employees in order to achieve the goals of the university and develop the personnel. If the training needs of the employees are determined correctly, the training will contribute to both their job-oriented and personal development, and also meet their educational expectations.

The success of the managers has also been effective in increasing the performance efficiency of university employees. Thus, in order to increase the loyalty and performance of the employees of the university, managers should be more social. The importance of performance evaluation is increasingly gaining in value within HRM. The rapid change and development in the world have caused organizations to enter an intensely competitive environment. The only way to achieve real productivity is to make the most effective use of human resources by organizations. Universities should establish evaluation systems according to their strategic goals and structure by training both evaluated and evaluating personnel. Training and development activities increase the professional and technical knowledge of the employees as well as improve their physical abilities and general culture. Also, the employee can improve his/her knowledge and skills regarding the job and improve wage opportunities by advancing in the career steps through trainings. As a result of this research, we have developed reccomendations for each factor of this study:

R1: A work environment free from stress and conflicts must be created in university in order to productively work. The desire of female employees to participate in an active work-life, to respond to their career expectations, and to have a sense of high esteem at the university can enable them to be stronger and more productive in both worklife and social life.

R2: Employees should be selected regardless of gender. Employees' opinions should be taken into account. Considering these as an opportunity for university development and providing equal opportunities in training and development to every employee may be beneficial in terms of achieving more efficiency and standing in a competitive environment.

R3: Considering the tendency of married employees towards training activities, the continuity of these activities should be ensured as a constant source of motivation. Determining the training needs and career expectations of single employees, training activities may be beneficial in terms of increasing employee performance.

R4: Increasing the performance of university's employees depends on the success of the managers. It is important for managers to see their employees as a social asset, not a material element, in order to 
increase their loyalty to the university. Considering the different expectations of all employees and paying attention to the social expectations of single employees will be beneficial in increasing employee motivation and performance.

R5: There are many different employees at the university in terms of their fields of duty and academic rank. For this reason, developing methods that will strengthen communication among employees by the university management and referring to the knowledge, experience and ideas of employees of all ranks without discrimination can provide significant benefits to the realization of the goals of both the university and the employees.

R6: While training activities increase the professional and technical knowledge of the employees, they also increase their general culture and physical abilities. With the help of training, the employee can improve his knowledge and skills in his job and reach better wage opportunities by career promotion. Regardless of the work experience, training activities, which will contribute to the individual and corporative development of the employees, can increase the rate of their benefit from these activities.

R7: Payment is generally considered as a tool used by universities to increase performance and motivation in order to achieve their strategic goals. Employees' performance can be increased by applying the performance-based payment system fairly and increasing motivation.

R8: The purpose of the training activities, which are implemented in order to increase the performance of university employees, should be oriented in learning. Universities that adopt this goal can eliminate the information obsolescence that occurs in individuals with the new knowledge and skills they acquire. High technology and knowledge, which is one of the most effective competitive elements in contemporary world, can only be achieved through well-programmed training activities. Correct determination of the subject and training programs can increase the training gains and performances of the employees.

\section{References}

Afshari, A., Mojahed, M., \& Yusuff, R. (2010). Simple additive weighting approach to personnel selection problem. International Journal of Innovation, Management and Technology, 1(5), 511-215.

Barba Aragón, M. I., Jiménez, D., \& Sanz Valle, R. (2014). Training and performance: The mediating role of organizational learning. BRQ Business Research Quarterly, 17, 161-173. https://doi.org/10.1016/j.cede.2013.05.003

Chahar, B., Hatwal, V., \& Sen, S. (2019). Employees training and its impact on learning and creativity: Moderating effect of organizational climate. Problems and Perspectives in Management, 17(2), 430-439. https://doi.org/10.21511/ppm.17(2).2019.33

Daoanis, L. E. (2012). Performance Appraisal System: It's Implication To Employee Performance. International Journal of Economics and Management Sciences, 2(3), 55-62.

Galvão, A. R., Marques, C. S. E., Ferreira, J. J., \& Braga, V. (2020). Stakeholders' role in entrepreneurship education and training programmes with impacts on regional development. Journal of Rural Studies, 74, 169-179. https://doi.org/10.1016/j.jrurstud.2020.01.013

Gruman, J. A., \& Saks, A. M. (2011). Performance management and employee engagement. Human Resource Management Review, 21(2), 123-136. https://doi.org/10.1016/j.hrmr.2010.09.004

Harrington, D. (2009). Confirmatory Factor Analysis. In Confirmatory Factor Analysis. Oxford University Press. https://doi.org/10.1093/acprof:oso/9780195339888.001.0001

Holcomb, Z. C., Cox, K. S., Holcomb, Z. C., \& Cox, K. S. (2018). One-Way ANOVA. In Interpreting Basic Statistics (pp. 154-157). https://doi.org/10.4324/9781315225647-50

Ibrahim, R., Boerhannoeddin, A., \& Bakare, K. K. (2017). The effect of soft skills and training methodology on employee performance. European Journal of Training and Development, 41(4), 388-406. https://doi.org/10.1108/EJTD-08-2016-0066

Khan, R. A. G., Khan, F. A., \& Khan, M. A. (2011). Impact of Training and Development on Organizational Performance. Global Journal of Management and Business Research, 11(7), 63-69.

King, A. C., Rao, M. P., \& Tregillis, C. D. (2017). Econometric Analysis. In Litigation Services Handbook: The Role of the Financial Expert: Sixth Edition. Wiley Blackwell. https://doi.org/10.1002/9781119363194.ch9

Leroy, H., Segers, J., van Dierendonck, D., \& den Hartog, D. (2018). Managing people in organizations: Integrating the study of HRM and leadership. In Human Resource Management Review. https://doi.org/10.1016/j.hrmr.2018.02.002

McCrie, R. D. (2007). Training and Development for High Performance. In Security Operations Management (pp. 95120). Elsevier. https://doi.org/10.1016/b978-075067882-7/50043-6

Mpofu, M., \& Hlatywayo, C. K. (2015). Training and development as a tool for improving basic service delivery; the case of a selected municipality. Journal of Economics, Finance and Administrative Science, 20, 133-136. https://doi.org/10.1016/j.jefas.2015.10.004

Sharma, A. K., Joshi, A., \& Jurwall, V. (2020). Performance measurement metrics in TPM: A contextual view to training and development. Materials Today: Proceedings, 2476-2480. https://doi.org/10.1016/j.matpr.2020.04.796 
Sharma, S., \& Taneja, M. (2018). The effect of training on employee performance. International Journal of Recent Technology and Engineering, 7(4), 6-13.

Shibayama, S. (2019). Sustainable development of science and scientists: Academic training in life science labs. Research Policy, 48, 676-692. https://doi.org/10.1016/j.respol.2018.10.030

Singh, A. (2018). Continuous performance-based feedback and justice perceptions: Evidence for mediation by experienced participation. IIMB Management Review, 30, 134-139. https://doi.org/10.1016/j.iimb.2018.01.005

Vinesh, P. (2014). Role of Training \& Development in an Organizational Development. International Journal of Management and International Business Studies, 4(2), 212-220.

\section{Б. Абдрасилов, Ж. Кудайбергенов, Д. Келесбаев, С. Баймаганбетов \\ Адам ресурстарын басқару тәжірибелерін талдау: тренингтің Ахмет Ясауи университеті қызметкерлерінің жұмыс өнімділігіне әсері}

\section{Аңдатпа}

Maқ̧саты: Адам ресурстарын басқару жүйесі ұйымның барынша тиімді нәтижеге қол жеткізуі үшін маңызды рөл ойнайды. Мақаланың мақсаты - университет оқытушылары мен қызметкерлерінің жеке сипаттамалары мен адам ресурстарын басқару тәжірибелері арасындағы байланысты, сондай-ақ тренингтердің олардың өнімділік нәтижелеріне әсерін анықтау.

Әдістері: Авторлар деректерді жинау кезінде сауалнама әдісін және оларды бағалау үшін 5-балдық Ликерт жүйесін қолданды. Содан кейін алынған мәліметтер SPSS Statistics бағдарламасы арқылы талданды. Мақалада факторлық талдау, Т-тест, Anova тесті, регрессиялық талдау әдістері қолданылды.

Қорытынды: Мақалада тренингтердің, атап айтқанда, қанағаттану факторы мен ынталандыру факторының оқытушылар мен қызметкерлердің өнімділігіне әсері анықталды. Яғни, қанағаттану коэффициенті бір бірлікке өскен кезде өнімділік деңгейі 0,145 бірлікке төмендейді. Ал, өнімділік пен ынталандыру факторының арасында оң байланыс бар. Егер ынталандыру коэффициенті бір бірлікке артса, онда өнімділік деңгейі де 0,413 бірлікке артады.

Тұжырымдама: Тренинг іс-шаралары оқытушылар мен қызметкерлердің кәсіби және техникалық білімін жетілдіреді. Сонымен қатар, олардың қабілеттері мен ұйымдық мәдениетін арттырады. Осылайша, оларды үнемі оқыту арқылы бәсекеге қабілетті жұмыс ортасын қамтамасыз ету қажет.

Kiлm сөздер: адам ресурстарын басқару, адам ресурстарын басқару тәжірибелері, тренинг, өнімділік көрсеткіші, университет, қанағаттану факторы, ынталандыру факторы, қызметкер, оқытушы.

\section{Б. Абдрасилов, Ж. Кудайбергенов, Д. Келесбаев, С. Баймаганбетов}

\section{Анализ практики управления человеческими ресурсами: влияние тренинга на эффективность работы сотрудников Университета Ахмета Ясави}

\section{Аннотация}

Цель: Система управления человеческими ресурсами обеспечивает необходимое руководство для достижения эффективного результата наиболее действенным способом. Целью данной статьи является определение связи между описательными характеристиками преподавателей и сотрудников университета и практиками управления человеческими ресурсами, а также влияние тренинга на производительность сотрудников.

Memodbl: Авторы использовали метод анкетирования при сборе данных и 5-балльную систему Лейкерта для их оценки. Затем полученные данные были проанализированы с помощью программы SPSS Statistics. Kроме того, они применили факторный анализ, T-тест, ANOVA-тест, методы регрессионного анализа.

Pезультаты: В статье определяется влияние тренинга, а именно фактора удовлетворенности и фактора мотивации, на уровень производительности преподавателей и сотрудников. Когда коэффициент удовлетворенности увеличивается на одну единицу, уровень производительности снижается на 0,145 единицы. Между производительностью и фактором мотивации существует положительная корреляция. Если фактор мотивации увеличится на одну единицу, уровень производительности также возрастет на 0,413 единицы.

Bblвoдbl: Тренинги повышают профессиональные и технические знания преподавателей и сотрудников, а также улучшают их способности и корпоративную культуру. Таким образом, необходимо обеспечить рабочую среду, в которой они могут постоянно учиться и развиваться посредством тренингов.

Ключевые слова: управление человеческими ресурсами, практики УЧР, тренинг, показатель производительности, университет, фактор удовлетворенности, мотивационный фактор, сотрудник, преподаватель.

\section{References}

Afshari, A., Mojahed, M., \& Yusuff, R. Simple additive weighting approach to personnel selection problem, International Journal of Innovation, Management and Technology. — 2010. — № 1(5). — P. 511-215.

Barba Aragón, M. I., Jiménez, D., \& Sanz Valle, R. Training and performance: The mediating role of organizational learning, BRQ Business Research Quarterly. — 2014. — № 17. — P. 161-173. https://doi.org/10.1016/j.cede.2013.05.003 
Chahar, B., Hatwal, V., \& Sen, S. Employees training and its impact on learning and creativity: Moderating effect of organizational climate, Problems and Perspectives in Management. — 2019. — № 17(2). — P. 430-439. https://doi.org/10.21511/ppm.17(2).2019.33

Daoanis, L. E. Performance Appraisal System: It's Implication To Employee Performance, International Journal of Economics and Management Sciences. - 2012. - № 2(3). - P. 55-62.

Galvão, A. R., Marques, C. S. E., Ferreira, J. J., \& Braga, V. Stakeholders' role in entrepreneurship education and training programmes with impacts on regional development, Journal of Rural Studies. — 2020. — № 74. — P. $169-179$. https://doi.org/10.1016/j.jrurstud.2020.01.013

Gruman, J. A., \& Saks, A. M. Performance management and employee engagement, Human Resource Management Review. - 2011. — № 21(2). — P. 123-136. https://doi.org/10.1016/j.hrmr.2010.09.004

Harrington, D. Confirmatory Factor Analysis. In Confirmatory Factor Analysis. - Oxford University Press, 2009. https://doi.org/10.1093/acprof: oso/9780195339888.001.0001

Holcomb, Z. C., Cox, K. S., Holcomb, Z. C., \& Cox, K. S. One-Way ANOVA// Interpreting Basic Statistics. Routledge 2018. — P. 154-157. https://doi.org/10.4324/9781315225647-50

Ibrahim, R., Boerhannoeddin, A., \& Bakare, K. K. The effect of soft skills and training methodology on employee performance, European Journal of Training and Development. - 2017. - № 41(4). — P. 388-406. https://doi.org/10.1108/EJTD-08-2016-0066

Khan, R. A. G., Khan, F. A., \& Khan, M. A. Impact of Training and Development on Organizational Performance, Global Journal of Management and Business Research. — 2011. — № 11(7). — P. 63-69.

King, A. C., Rao, M. P., \& Tregillis, C. D. Econometric Analysis. In Litigation Services Handbook: The Role of the Financial Expert: Sixth Edition. — Wiley Blackwell, 2017. https://doi.org/10.1002/9781119363194.ch9

Leroy, H., Segers, J., van Dierendonck, D., \& den Hartog, D. Managing people in organizations: Integrating the study of HRM and leadership // Human Resource Management Review, 2018. https://doi.org/10.1016/j.hrmr.2018.02.002

McCrie, R. D. Training and Development for High Performance, Security Operations Management. — 2007. — № 2 P. 95-120. https://doi.org/10.1016/b978-075067882-7/50043-6

Mpofu, M., \& Hlatywayo, C. K. Training and development as a tool for improving basic service delivery; the case of a selected municipality, Journal of Economics, Finance and Administrative Science. — 2015. — № 20. — P. 133136. https://doi.org/10.1016/j.jefas.2015.10.004

Sharma, A.K., Joshi, A., \& Jurwall, V. Performance measurement metrics in TPM: A contextual view to training and development / Materials Today: Proceedings. — 2020. — P. 2476-2480. https://doi.org/10.1016/j.matpr.2020.04.796

Sharma, S., \& Taneja, M. The effect of training on employee performance, International Journal of Recent Technology and Engineering. — 2018. — № 7(4). — P. 6-13.

Shibayama, S. Sustainable development of science and scientists: Academic training in life science labs, Research Policy. — 2019. — № 48. — P. 676-692. https://doi.org/10.1016/j.respol.2018.10.030

Singh, A. Continuous performance-based feedback and justice perceptions: Evidence for mediation by experienced participation, IIMB Management Review. — 2018. — № 30. — P. 134-139. https://doi.org/10.1016/j.iimb.2018.01.005

Vinesh, P. Role of Training \& Development in an Organizational Development, International Journal of Management and International Business Studies. - 2014. - № 4(2). — P. 212-220. 